\title{
The Information Commons Handbook (review)
}

Robert A. Seal

Loyola University Chicago, rseal@luc.edu

Follow this and additional works at: https://ecommons.luc.edu/lib_facpubs

Part of the Library and Information Science Commons

\section{Recommended Citation}

Seal, Robert A. "The Information Commons Handbook (review)." Portal: Libraries and the Academy 7, no. 3 (2007): 389-390.

This Article is brought to you for free and open access by the Faculty Publications and Other Works by Department at Loyola eCommons. It has been accepted for inclusion in University Libraries: Faculty Publications and Other Works by an authorized administrator of Loyola eCommons. For more information, please contact ecommons@luc.edu.

\section{(c) (1) () $\Theta$}

This work is licensed under a Creative Commons Attribution-Noncommercial-No Derivative Works 3.0 License. Copyright @ 2007 The Johns Hopkins University Press 


\section{Project \\ MUSE \\ Today's Research. Tomorrow's Inspiration.}

\section{The Information Commons Handbook}

Seal, Robert A.

portal: Libraries and the Academy, Volume 7, Number 3, July 2007, pp. 389-390 (Review)

Published by The Johns Hopkins University Press DOI: 10.1353/pla.2007.0037

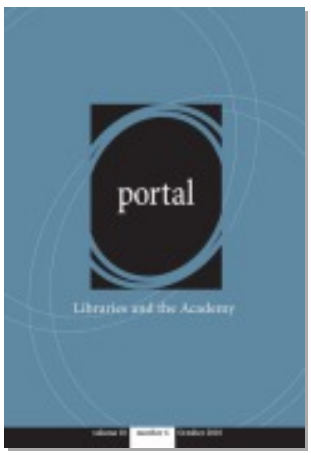

For additional information about this article http://muse.jhu.edu/journals/pla/summary/v007/7.3seal.html 
The Information Commons Handbook, Donald Robert Beagle. NY: Neal-Schuman Publishers, Inc., 2006. 247p. with CD-ROM \$125 (ISBN 1-55570-562-6)

Once an innovative idea but now a standard feature of many academic libraries, the information commons has transformed library services across the country over the past decade. Although dozens of articles have appeared in the literature on various aspects and models of the information commons (IC), until now there has not been a thorough monograph devoted to the topic. And who better to write that book than Donald Beagle, director of library services at Belmont Abbey College? Although not the inventor of the information commons, Beagle is a pioneer in the development of the concept and is perhaps the best-known name in the field. His influential and seminal article entitled “Conceptualizing an Information Commons" (Journal of Academic Librarianship 25, 2 (1999): 82-9) has been cited countless times and is required reading for librarians seeking to implement an IC in their own institutions.

While the IC concept originated in college and university libraries and remains primarily an academic library program, it is now appearing in public libraries and even some school libraries that wish to be more responsive to user needs. Therefore, the book is appropriate for any library with an interest in creating an IC or enhancing an existing one as it explores both theory and practice while emphasizing the importance of thorough planning in program development.

Beagle, who developed and directed the IC at the University of North Carolina at Charlotte, wrote in the aforementioned article that the information commons existed in two states, virtual and physical. In the Handbook, he expands this framework to include a third form, the "cultural commons," which he defines as "the social, political, legal, regulatory, and economic envelope surrounding creative expression, public speech, popular and academic publishing, and scholarly inquiry." (p. 5) This latest model is the natural outgrowth of trends such as group study, learning communities, writing centers, and, most recently, social networking and other aspects of Web 2.0. The book thus recognizes that the IC continues to evolve, as it must, in response to changes in user needs and expectations, technology, pedagogy, and society.

The book is organized in three major sections. Part I: "How the Information Commons Can Transform Knowledge and Information" addresses the three manifestations described above, the first of which is the primary, but not exclusive, focus of the Handbook. Here Beagle looks at the underlying theory of the IC and underscores the notion that it is not merely a computer lab but rather technology supported by human resources in an environment where the library is closely allied with the teaching and learning mission of the university. In reviewing the history of the $\mathrm{IC}$, he notes that it has brought together the formerly disparate "islands" of reference, media, and data services at a technological intersection that supports the learning process. An examination of the evolution of the IC to into the broader "learning commons" (LC) and the role of information literacy in that transformation is the focus of the third chapter. The author describes the roles of the IC's human, physical, digital, and social resources in support of the LC, giving one of the most thorough and thoughtful analyses of its type in the literature.

Part II, "Designing and Building the Physical Commons," the core of the book, 
has two purposes: (1) planning a new IC or LC and (2) planning for the transformation of an existing IC to a more comprehensive LC. There is an appropriate emphasis in this section on strategic planning based in large measure on user feedback. Beagle offers a useful five-step planning template adaptable to any library situation: self-discovery, scenario-building, projecting the future commons, managing the campus conversation, and drafting the project document. He discusses each step in detail and uses illustrations from actual IC planning activities at a number of libraries. Whether a library has the time, resources, and energy to undertake such a thorough analysis is another matter, but certainly the Beagle planning model is worthy of study and consideration.

Part III, "Making Vision Reality," rounds out this fine book with a variety of practical topics beginning with IC implementation and all its requisite elements: management, staffing, budgeting, project calendars, and so on. His recommendation of four teams (implementation, physical resources, digital resources, human resources, and social resources), although ideal, seems overly ambitious for all but the largest of libraries. On the other hand, the numerous tasks presented may serve as a useful checklist for a successful project. Other topics addressed in part III include marketing, assessment, and practical public policies.

Despite the fact that Beagle could probably have written a useful guide to the IC off the top of his head, he chose instead to combine his own experiences with those of others in a thoroughly researched and thought-provoking volume that will be of use to practitioners and administrators alike.

Robert A. Seal

Loyola University Chicago rseal@luc.edu

Information Literacy Instruction that Works: A Guide to Teaching by Discipline and Student Population, ed. Patrick Ragains. New York: Neal-Schuman, 2006. 329p. with CD-ROM $\$ 89.95$ (ISBN 1-55570573-1)

\section{Information Literacy Collaborations that} Work, ed. Trudi E. Jacobson and Thomas Mackey. New York: Neal-Schuman, 2007. 264p. \$85 (ISBN 1-55570579-0)

These two volumes are recent additions to the series Information Literacy Sourcebooks, a forum to share ideas and practical advice about research skills education in academia. The collection of essays edited by Patrick Ragains, a librarian at the University of Nevada, Reno, addresses the audience of professionals involved in information literacy instruction (ILI) to specific groups such as students with disabilities, community college students, firstyear undergraduates, distance learners, disciplinary majors, or patent researchers. Contributors are academic librarians who represent a variety of institutional experience and disciplinary expertise.

Information Literacy Instruction that Works appeals to both new and seasoned professionals because the editor prefaces the more narrowly focused chapters with essays that introduce the fundamentals of ILI in the academic setting. The collection recommends tested strategies for adapting general information literacy (IL) concepts to the learning needs of special groups. Even more practically, it offers examples of lesson plans, resource lists, assessment tools, exercises, promotional tools, and other resources. The included CD-ROM facilitates customization of these samples.

As part of the same series, Information Literacy Collaborations that Work shares many characteristics with Information Literacy Instruction that Works. Both collections 